\begin{abstract}
Iranica
Abstracta Iranica Revue bibliographique pour le domaine irano-aryen

Volume 34-35-36 | 2017

Comptes rendus des publications de 2011-2013
\end{abstract}

\title{
Javier Àlvarez-Mon. Elam in the Iron Age
}

\section{Rémy Boucharlat}

\section{OpenEdition}

Journals

Édition électronique

URL : http://journals.openedition.org/abstractairanica/42178

DOI : 10.4000/abstractairanica.42178

ISSN : 1961-960X

Éditeur :

CNRS (UMR 7528 Mondes iraniens et indiens), Éditions de l'IFRI

\section{Référence électronique}

Rémy Boucharlat, " Javier Àlvarez-Mon. Elam in the Iron Age », Abstracta Iranica [En ligne], Volume 34-35-36 | 2017, document 125, mis en ligne le 30 juillet 2017, consulté le 26 septembre 2020. URL : http://journals.openedition.org/abstractairanica/42178; DOI : https://doi.org/10.4000/ abstractairanica. 42178

Ce document a été généré automatiquement le 26 septembre 2020.

Tous droits réservés 


\title{
Javier Àlvarez-Mon. Elam in the Iron
}

\section{Age}

\author{
Rémy Boucharlat
}

\section{RÉFÉRENCE}

Javier Àlvarez-Mon. « Elam in the Iron Age », in: D.T. Potts, ed., The Oxford Handbook of Ancient Iran. New York, Oxford University Press, 2013, p. 456-477.

1 En Elam (la plaine et le piémont du Khuzestan, et le Fars), la période Néo-Elamite I (1000-725) et II (725-520) équivaut aux Age du Fer II et III du Zagros, mais cette périodisation surtout archéologique, n'est pas la même chez les historiens et épigraphistes (Voir c.r. n 126, de la même rubrique 3-2-2). L'A. synthétise utilement les travaux archéologiques menés sur Suse, les prospections récentes (Shushtar et piémont du Zagros) et les importantes découvertes des deux tombes princières près de Behbahan en 1982 et près de Ram Hormoz en 2007. Cette revue fait bien ressortir la pauvreté de la période néo-élamite I par rapport à la suivante, et plus encore la renaissance du dernier siècle avant les Achéménides dans la plaine et le piémont (entre autres, les tombes princières), mais pas (encore) dans le Fars central pour lequel la théorie du retour au nomadisme, qui repose surtout sur l'absence de témoins archéologiques, reste majoritaire mais contestable. 


\section{AUTEURS}

RÉMY BOUCHARLAT

UMR 5133 CNRS-Université de Lyon 